\title{
The Use of Phenolic Wastewater in Coke Production
}

\author{
Anna Kwiecińska*, Jan Figa, Sławomir Stelmach \\ Institute for Chemical Processing of Coal, \\ Zamkowa 1, 41-803 Zabrze, Poland
}

Received: 16 October 2014

Accepted: 10 November 2015

\begin{abstract}
The huge amount of phenolic wastewater generated at coke oven plants is nowadays partially utilized during the wet coke quenching process. The stream, however, contains a range of inorganic compounds (i.e., chlorides, alkali and sulphates), the presence of which in the coke is highly undesired. Moreover, the impact on the quenching water composition on the final quality of coke, considering the concentrations of mineral contaminants, is unknown. Our paper investigates the composition of quenching water - in particular the impact of chlorides and sodium ion content on the final quality of wet-quenched coke. We used dry-quenched coke, treated rainfall, and treated phenolic wastewater generated at one the largest coke plants in Poland. Our study showed the existence of linear dependences between chlorides and sodium ion content in quenching water, and their final amount in the wet-quenched coke. We developed the calculation procedure of the maximum share of the treated phenolic wastewater in the quenching water stream, at which the contract parameter of coke could be held, based on the basis of our experimental results.
\end{abstract}

Keywords: treated phenolic wastewater, wet coke quenching, chlorides, sodium ions

\section{Introduction}

The coke-making process results in the generation of a huge amount of highly loaded industrial wastewater. It is assumed that $0.6 \mathrm{~m}^{3}$ of wastewater is generated for every ton of produced coke, which, considering annual worldwide production of coke at the level of ca. 670 million tons (2013), comes out to ca. 402 million $\mathrm{m}^{3}$ of wastewater. This wastewater, also called phenolic wastewater, is contaminated with a wide range of organic and inorganic compounds and must undergo various treatment processes. The treatment technology involves a series of mechanical, chemical, and biological operations

*e-mail: akwiecinska@ichpw.pl that should be arranged in such a way as to allow for the final stream to be safely deposited in the environment. The contaminants most notable during consideration of the treatment technology are cyanides, sulphides, suspended tars, phenols, and ammonia. A number of studies all over the world have been carried out in order to improve the performance of treatment processes in the field of the efficient removal of those contaminants. The final parameters of the treated stream, according to the content of those compounds, must fulfill very sharp standards given in proper regulations [1-6]. Regardless of treatment efficiency, the deposition of purified wastewater stream to the environment generates additional costs to a plant operation and it is highly undesired considering the modern configuration of industrial plants, i.e., a zeroliquid discharge system. Hence, due to the fact that the load 
of priority contaminants present in phenolic wastewater is reduced to a very low level, coke oven plants try to apply the partial utilization of the treated stream via wetquenching of coke [7-10].

The quality of coke is a very important parameter considering its further use. More than $90 \%$ of worldwide coke production is dedicated to the blast furnace process, during which pig iron is produced. The role of coke in the blast furnace operation is crucial to overall process performance, i.e. [11-14]:

- It supplies energy required for all endothermic reactions that occur during the process.

- It is a source of both reduction gases for iron oxides and carbon for pig-iron carbonization.

- It is a gas-permeable barrier that assures the up-flow of hot gases and down-flow of metal and slag within the furnace.

Hence, the coke introduced to the blast furnace process must be of the highest quality. The qualitative parameters of coke depend on a series of factors, among which the quality of coal blend used for coke production, the coking process conditions, and, finally, the quenching method applied are of the highest importance. When the coke is considered to be dedicated to the blast furnace process, it must correspond to a range of demands in which the content of inorganic compounds - especially chlorine and alkali metals - can be found. Limitations on the amount of those substances in coke result from their action in blast furnace construction. Chlorine, when evolved to the gaseous phase, forms hydrochloric acid, which is responsible for the corrosion of furnace devices, while sodium salts are the main component of deposits formed on the furnace walls, which may lead to serious process interruptions [15-17].

There are two main methods of coke quenching applied at the coke plants all over the world, i.e., the dry and wet methods. In the dry method the hot coke pushed out of the battery undergoes contact with the cooling medium, which is usually inert gas. In the latter method, the hot coke is sprayed with the cooling water in the devices, called cooling tower. A comparison of both methods is given in Table 1.

Despite the fact that the dry quenching method seems to be more advantageous, considering the final quality of coke, due to economic factors it is wet quenching that is most often applied at coke plants (in Poland only two coke plants among nine are equipped with dry-coke quenching). Hence, the optimization of the process due to the composition of quenching water is crucial for the production of coke of desired quality.

Wet quenching of coke with water containing chlorides and sodium ions results in the increase of their content in the coke. Nevertheless, the amount of those inorganics present in the hot coke, pushed out from the battery, is usually below limits. As both chlorides and sodium ions are also present in high amounts in treated phenolic wastewater, it is possible to apply it in wet-coke quenching, depending on the load of minerals they can introduce to the process, i.e., their maximum share in the quenching stream. Hence, it is very important to know the effects of the mineral contaminants concentration in quenching water on their final content in the coke.

Our article discusses the impact of the treated phenolic wastewater parameters on the quenching water quality, and, simultaneously, on wet-quenched coke quality. The aim of our study was to show that the partial utilization of treated phenolic wastewater via quenching technology would affect final coke quality only in a controlled way, and that it would also improve the overall coke plant action on the environment by minimizing the amount of emitted contaminants.

\section{Materials and Methods}

For the study, we used dy quenched coke, treated rainfall and phenolic wastewater collected at one of the largest Polish coke plants. The use of dry-quenched coke enabled us to investigate the material, the quality of which was not affected by the industrial quenching process. Hence, its composition should have corresponded to the composition of hot coke pushed out from the coke oven battery. The characteristic of process streams is given in Tables 2 (coke) and 3 (wastewaters).

In order to perform the wet quenching process, samples of dry-quenched coke were placed in the retort and heated up to $1,000^{\circ} \mathrm{C}$. Such a temperature allowed us to simulate the process conditions of a coke oven battery, which it attained relatively quickly so that no further evolution of the volatiles from the heated material took place. The obtained hot coke was next placed in a basket and quenched with water. The experiment covered 10 tests, during which five different quenching streams were used. The coke was quenched with only treated phenolic

Table 1. The comparison of coke quenching methods.

\begin{tabular}{|c|c|c|}
\hline \multirow{2}{*}{ Advantages } & Wet quenching & Quenching method \\
\cline { 2 - 3 } & $\begin{array}{c}\text { The cheapest quenching method } \\
\text { Simple devices } \\
\text { Full automation of the process }\end{array}$ & $\begin{array}{c}\text { Coke heat recovery } \\
\text { No impact on coke quality }\end{array}$ \\
\hline \multirow{2}{*}{ Disadvantages } & $\begin{array}{c}\text { Loss of coke heat } \\
\text { Emission from wet quenching tower } \\
\text { Affection of coke quality }\end{array}$ & $\begin{array}{c}\text { Complicated constructions and devices Emission of dusts } \\
\text { Significant electrical energy demand } \\
\text { (fans, dedusting devices, filters, etc.) }\end{array}$ \\
\hline
\end{tabular}


Table 2. The characteristics of dry-quenched coke samples used in the study.

\begin{tabular}{|c|c|c|}
\hline Parameter & Series 1 & Series 2 \\
\hline Total moisture, $\mathrm{W}_{\mathrm{t}}^{\mathrm{r}}, \%$ & 0.3 & 0.1 \\
\hline Ash in dry state, $\mathrm{A}^{\mathrm{d}}, \%$ & 9.4 & 9.6 \\
\hline Volatile matter in dry state, $\mathrm{V}^{\mathrm{d}}, \%$ & 0.42 & 0.3 \\
\hline $\mathrm{Chlorine}^{\mathrm{C}} \mathrm{Cl}^{\mathrm{a}} \%$ & 0.053 & 0.053 \\
\hline $\mathrm{Na}_{2} \mathrm{O}$ in ash, \% & 1.88 & 1.91 \\
\hline $\mathrm{K}_{2} \mathrm{O}$ in ash, $\%$ & 2.17 & 2.22 \\
\hline
\end{tabular}

wastewater or only treated rainfall wastewater, or their mixtures containing 25,50 , and $75 \% \mathrm{v} / \mathrm{v}$ of phenolic wastewater. The content of chlorides and sodium ions in particular quenching water streams was:

- Stream 1: 100\% v/v TRW: $181 \mathrm{mgCl}^{-} / \mathrm{dm}^{3}, 107 \mathrm{mgNa}^{+} /$ $\mathrm{dm}^{3}$

- Stream 2: $25 \% \mathrm{v} / \mathrm{v}$ TPhW, 75\% v/v TRW: $834 \mathrm{mgCl}^{-} /$ $\mathrm{dm}^{3}, 953 \mathrm{mgNa}^{+} / \mathrm{dm}^{3}$

- Stream 3: 50\% v/v TPhW, 50\% v/v TRW: $1487 \mathrm{mgCl} /$ $\mathrm{dm}^{3}, 1794 \mathrm{mgNa}^{+} / \mathrm{dm}^{3}$

- Stream 4: 75\% v/v TPhW, 25\% v/v TRW: $2410 \mathrm{mgCl}^{-} /$ $\mathrm{dm}^{3}, 2635 \mathrm{mgNa}^{+} / \mathrm{dm}^{3}$

- Stream 5: 100\% v/v TPhW: $2783 \mathrm{mgCl}^{-} / \mathrm{dm}^{3}, 3476$ $\mathrm{mgNa}^{+} / \mathrm{dm}^{3}$

Fig. 1 presents the scheme of the hot coke preparation and wet-quenching laboratory sites.

The quenched coke was weighed twice - immediately after the quenching and after the equilibrium between a wet sample and air humidity was obtained. Next we analyzed wet coke samples, including chlorine and sodium oxide content in the product.

\section{Results and Discussion}

Table 4 shows the characteristics of coke samples quenched with different water streams, while Figs 2 and 3 show the change of chlorine and sodium oxide contents in

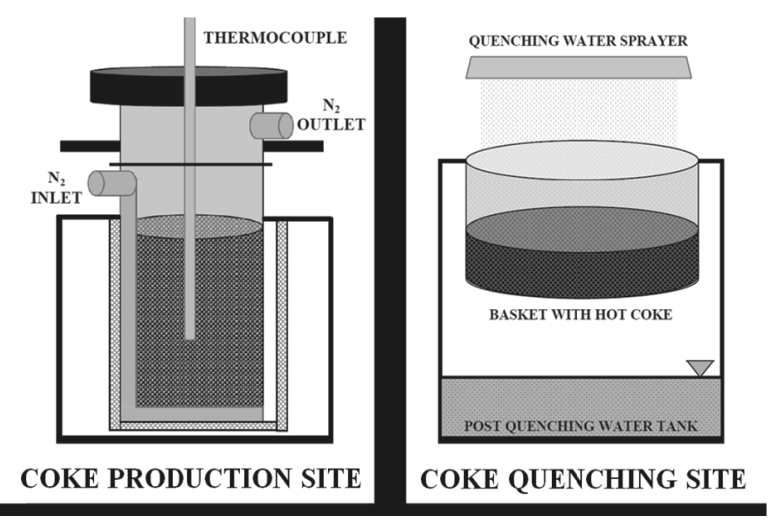

Fig. 1. Laboratory sites for hot coke preparation and wet-coke quenching.

the wet-quenched product as a dependence of chloride and sodium ion concentrations in quenching water.

The negligible differences concerning humidity, content of ash, and volatile parts in the coke. Thus it was concluded that those parameters were independent of quenching water composition. On the other hand, significant differences were observed when the amount of minerals (i.e., chlorine and sodium oxide) was considered (Figs 2 and 3).

It was found that with the increase of mineral ion concentrations in quenching water (i.e., with the increase of treated phenolic wastewater share in the stream) their increase in the wet-quenched coke was observed. Even though concentrations of both ions were comparable ranging from 181 to $2783 \mathrm{mg} / \mathrm{dm}^{3}$ in the case of chlorides, and from 107 to $3476 \mathrm{mg} / \mathrm{dm}^{3}$ in the case of sodium ions - their impact on coke quality differed. When the share of treated phenolic wastewater in the quenching stream was at $25 \%$, the chlorine concentration in coke increased by $32 \%$, while the content of sodium oxide in coke's ash changed only by $8 \%$. In the case of TPhW shares equal to 50 and $75 \%$ of the increase of chlorine content in product was $50 \%$, while for sodium oxide it was 14 and $15 \%$, respectively. The further change of mineral amounts in coke was obtained when it was quenched only with treated

Table 3. The characteristics of treated rainfall and phenolic wastewater used for wet-coke quenching.

\begin{tabular}{|c|c|c|c|}
\hline Parameter & Parameter & $\begin{array}{c}\text { Treated rainfall wastewater } \\
(\mathrm{TRW})\end{array}$ & $\begin{array}{c}\text { Treated phenolic wastewater } \\
(\mathrm{TPhW})\end{array}$ \\
\hline $\mathrm{pH}$ & ---8.8 & 110 \\
\hline Total suspended solids & $\mathrm{mg} / \mathrm{dm}^{3}$ & 5.8 & 245 \\
\hline Chemical Oxygen Demand, COD & $\mathrm{mgO} / \mathrm{dm}^{3}$ & 9.26 & 10145 \\
\hline Total Dissolved Solids & $\mathrm{mg} / \mathrm{dm}^{3}$ & 767 & 3472 \\
\hline Sodium as $\mathrm{Na}^{+}$ & $\mathrm{mg} / \mathrm{dm}^{3}$ & 107 & 5.4 \\
\hline Potassium as $\mathrm{K}^{+}$ & $\mathrm{mg} / \mathrm{dm}^{3}$ & 10.8 & 0.77 \\
\hline Ammonium nitrogen as $\mathrm{N}_{\mathrm{NH} 4}$ & $\mathrm{mg} / \mathrm{dm}^{3}$ & 0.2 & 2793 \\
\hline Chlorides as $\mathrm{Cl}^{-}$ & $\mathrm{mg} / \mathrm{dm}^{3}$ & 181 & \\
\hline
\end{tabular}


Table 4. Characteristics of wet-quenched coke obtained during the study.

\begin{tabular}{|c|c|c|c|c|c|c|c|}
\hline \multirow{2}{*}{$\begin{array}{l}\text { Test } \\
\text { no. }\end{array}$} & & \multicolumn{6}{|c|}{ Wet quenched coke parameters } \\
\hline & Quenching water type & $\mathrm{W}_{\mathrm{r},}^{\mathrm{t}} \%$ & $\mathrm{~A}^{\mathrm{a},} \%$ & $\mathrm{~V}^{\text {daf }}, \%$ & $\mathrm{Cl}^{\mathrm{a}}, \%$ & $\mathrm{Na}_{2} \mathrm{O}$ (coke's ash) & $\%$ weight loss ${ }^{*}$ \\
\hline 1 & \multirow{2}{*}{$\mathrm{TPhW}$} & 7.5 & 9.4 & 0.78 & 0.114 & 2.64 & 3.9 \\
\hline 2 & & 1.7 & 9.3 & 0.50 & 0.079 & 3.12 & 2.7 \\
\hline 3 & \multirow{2}{*}{ TRW } & 6.2 & 9.7 & 0.74 & 0.053 & 1.99 & 3.8 \\
\hline 4 & & 5.0 & 9.4 & 0.60 & 0.053 & 1.81 & 3.0 \\
\hline 5 & \multirow{2}{*}{$\begin{array}{l}75 \% \text { TPhW } \\
25 \% \text { TRW }\end{array}$} & 3.5 & 9.0 & 0.57 & 0.088 & 2.69 & 2.8 \\
\hline 6 & & 1.0 & 9.3 & 0.39 & 0.070 & 2.52 & 1.4 \\
\hline 7 & \multirow{2}{*}{$\begin{array}{c}50 \% \text { TPhW } \\
50 \% \text { TRW }\end{array}$} & 3.1 & 9.6 & 0.53 & 0.088 & 2.58 & 3.3 \\
\hline 8 & & 1.0 & 9.4 & 0.52 & 0.07 & 2.51 & 2.2 \\
\hline 9 & \multirow{2}{*}{$\begin{array}{c}25 \% \text { TPhW } \\
75 \% \text { TRW }\end{array}$} & 4.1 & 9.2 & 0.55 & 0.070 & 2.42 & 3.1 \\
\hline 10 & & 5.8 & 9.2 & 0.70 & 0.070 & 2.31 & 3.6 \\
\hline
\end{tabular}

phenolic wastewater, and increases of mineral amounts were at $77 \%$ for chlorine and $21 \%$ for sodium oxide. The obtained results enabled us to conclude that there existed a dependence between mineral ion concentrations in

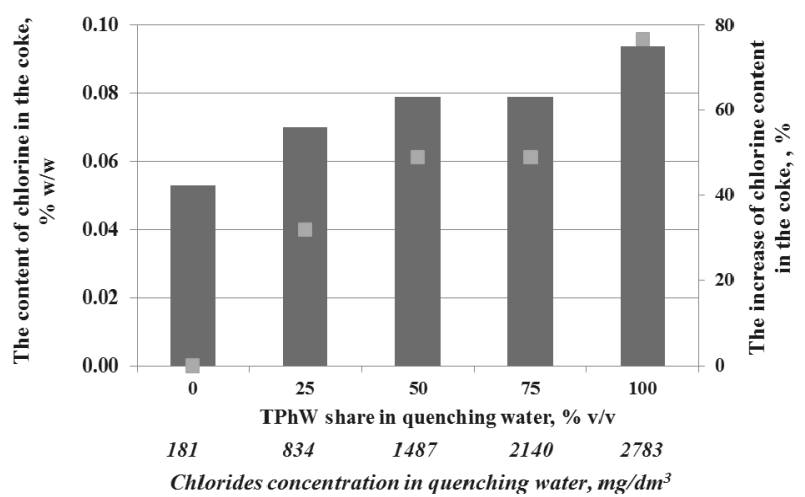

Fig. 2. Comparison of chlorine content in coke quenched with waters of different chloride concentrations.

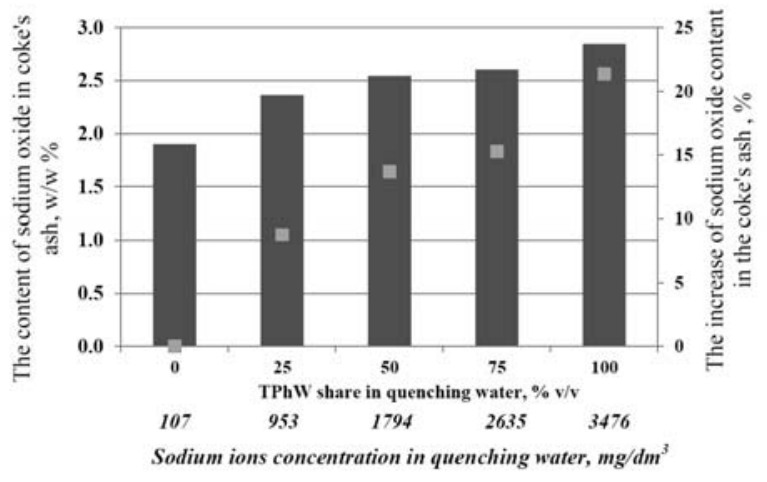

Fig. 3. Comparison of sodium oxide content in coke quenched with water of different sodium ion concentrations. quenching water and their final amount in the coke. Figs 4 and 5 show the impact of the quenching water composition on the increase of chlorine and sodium oxide content in the coke. This increase was calculated by the subtraction of the

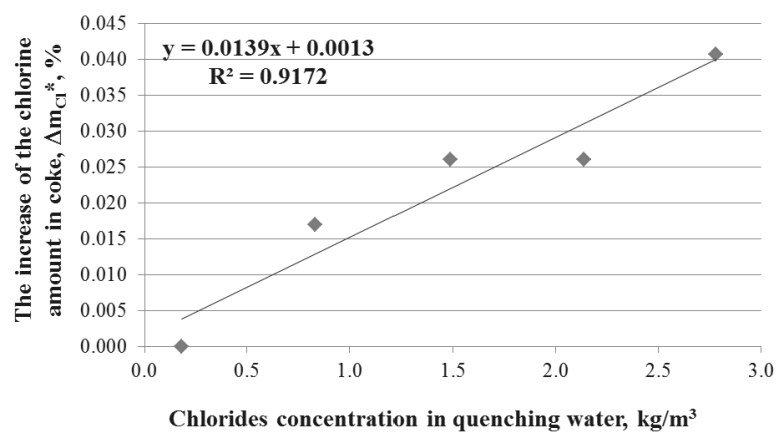

Fig. 4. The impact of chloride concentrations in quenching water on the increase of chlorine content in wet-quenched coke ("the increase refers to the chlorine content in the dry-quenched coke).

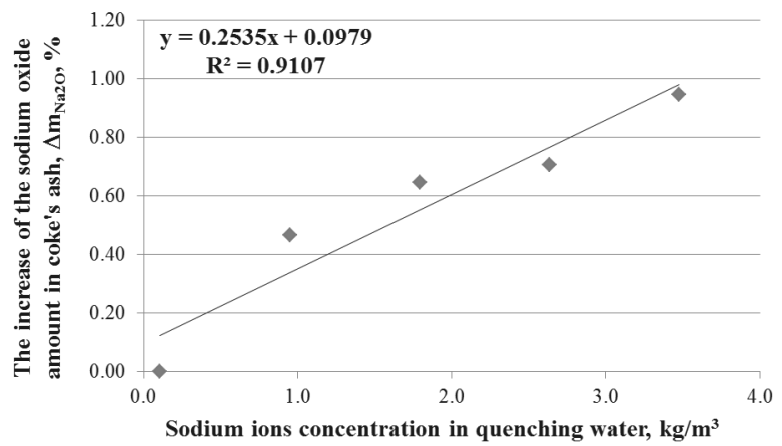

Fig. 5. The impact of sodium ion concentrations in quenching water on the increase of sodium oxide content in wet-quenched coke ("the increase refers to the sodium oxide content in the dryquenched coke's ash). 
investigated parameter value measured for dry-quenched coke from the one obtained for wet-quenched coke.

We found that both dependences could be described by linear equations with a satisfactory value of determination coefficient equal to $>0.91$. Regardless of the simplicity of equations, their usability for coke production is crucial. First of all, they enable us to predict how the quality of coke may change after quenching with water of a given composition. Secondly, they can be used to estimate if and what volume of treated phenolic wastewater, which introduces additional minerals load to the quenching water, can be directed to the process. This estimation can be done by the set of equations 1-3. The most important is to know the amount of inorganics in the hot coke, which corresponds to their amount in the dry-quenched coke prepared from the same coal blend (if such a value is not available, one may use literature data, which indicates that chlorine present in coal remains in coke in the amount of 40 to $60 \%$, while for sodium this coefficient is usually $90 \%$ ). The calculations are presented only for chlorine/chlorides, but the procedure is exactly the same in the case of sodium ions/sodium oxide. The procedure starts with the evaluation of the maximum amount of the contaminants (i.e., chlorine) that can be introduced to the coke with the quenching water (Eq.1):

$$
\Delta \mathrm{m}_{\mathrm{Cl}, \max }=\mathrm{m}_{\mathrm{Cl}, \lim }-\mathrm{m}_{\mathrm{Cl}, \mathrm{dc}}
$$

...where $\Delta \mathrm{m}_{\mathrm{Cl} \text {, max }}$ is the maximum amount of chlorine that can be introduced to the coke during the quenching process $(\% \mathrm{w} / \mathrm{w}), \mathrm{m}_{\mathrm{Cl}, \lim }$ is the permissible amount of chlorine in the produced coke limited by the recipient $(\%$ $\mathrm{w} / \mathrm{w})$, and $\mathrm{m}_{\mathrm{Cl}, \mathrm{dc}}$ is the amount of chlorine measured for the dry-quenched coke produced for the same coal blend composition ( $\% \mathrm{w} / \mathrm{w})$.

The amount of chlorine that can be accepted by the coke during the wet-quenching process is next introduced to the equation, which enables us to calculate the maximum concentration of chlorides in quenching water, i.e.:

$$
\mathrm{C}_{\mathrm{Cl}, \max }=\frac{\Delta \mathrm{m}_{\mathrm{Cl}, \max }-0.0013}{0.0139}
$$

...where $\mathrm{C}_{\mathrm{Clmax}}$ is the maximum permissible concentration of chlorides in the quenching water $\left(\mathrm{kg} / \mathrm{m}^{3}\right)$.

When the composition of quenching water considering maximum chlorides content is known (Eq. 2), then the share of treated phenolic wastewater in the quenching water stream (composed of treated phenolic and treated rainfall wastewater) can be established (Eq. 3):

$$
\mathrm{S}_{\mathrm{TPhW}}=\frac{100\left(\mathrm{C}_{\mathrm{Cl}, \mathrm{max}}-\mathrm{C}_{\mathrm{Cl}, \mathrm{TRW}}\right)}{\mathrm{C}_{\mathrm{Cl}, \mathrm{TPhW}}-\mathrm{C}_{\mathrm{Cl}, \mathrm{TRW}}}
$$

...where $\mathrm{S}_{\mathrm{TPhW}}$ is the maximum share of treated phenolic wastewater in the quenching water stream $(\% \mathrm{v} / \mathrm{v})$, $\mathrm{C}_{\mathrm{Cl} \text {, TRW }}$ is the concentration of chloride in treated rainfall wastewater $\left(\mathrm{kg} / \mathrm{m}^{3}\right)$, and $\mathrm{C}_{\mathrm{Cl} \text {, TPhW }}$ is the concentration of chlorides in treated phenolic wastewater $\left(\mathrm{kg} / \mathrm{m}^{3}\right)$.
The above procedure may be used to significantly improve the water and wastewater management systems of a coke plant. It allows us to partially close the cycle of treated phenolic wastewater by its utilization via a quenching process with the known share of the stream in the overall quenching water amount. This also leads to savings generation - both environmental and economic. As the smaller amount the wastewater is deposited to the environment, the load of contaminant introduced to an external collector is smaller and the environmental fee is decreased. Another savings may, in parallel, be made by the decrease of the amount of water required for quenching purposes, which must be bought from an external supplier.

\section{Conclusions}

In the article the impact of quenching water composition, in particular the content of mineral ions (i.e., chlorides and sodium ions) on the quality of wet-quenched coke, is discussed. The paper also shows the optimization of insitu utilization of treated phenolic wastewater for wet-coke quenching purposes. A range of experiments investigating the impact of the quenching water parameters on the final coke quality was run. The study showed that linear dependencies exist between concentrations of chlorides and sodium ions in quenching water and their final content in the wet-quenched coke. Those dependences were further used as the basis for elaboration of calculation procedures dedicated to determination maximum permissible shares of treated phenolic wastewater that could be introduced to the process. Such a solution of treated phenolic wastewater management is very advantageous, as it improves the final quality of the produced coke, the environmental effect of the coke plant, and economics. Knowledge of the impact of quenching water quality on coke parameters will enable coke oven plant operators to compose optimal quenching water streams or to predict the composition of the product, which will be obtained in the quenching process with water of given parameters. Moreover, if treated wastewater is partially utilized via the quenching process, a smaller load of contaminants is deposited to the environment, which is accompanied by a decrease in the environmental fee that must be paid by the plant. Additionally, the amount of water that needs to be supplied for quenching purposes is also decreased, which also generates savings.

\section{Acknowledgements}

This study was financed under the Smart Coking Plant R\&D Project (Innovative Economy Programme (POIG), contract No. 01.01.02.-24- 017/08).

\section{References}

1. VAZQUEZ I., RODRIGUEZ J., MARANON E., CASTRI;;PM L., FERNANDEZ Y., Simultaneous removal 
of phenol, ammonium, thiocyanate from coke wastewater by means of aerobic biodegradation, Journal of Hazardous Materials B137, 1773, 2006.

2. WEI X., ZHANG Z., FAN Q., YUAN X., GUO D., The effect of treatment stages on the coking wastewater hazardous compounds and their toxicity, Journal of Hazardous Materials 230-240, 135, 2012

3. PARK D., KIM Y., LEE D., PARK J., Chemical treatment for treating cyanides-containing effluent from biological cokes wastewater treatment process, Chemical Engineering Journal 143, 141, 2008.

4. CHENG Y., FAN W., GUO L., Coking wastewater treatment using a magnetic porous ceramsite carrier, Separation and Purification Technology 130, 167, 2014.

5. SHEN J., ZHAO H., CAO H., ZNAHG Y., CHEN Y., Removal of total cyanide in coking wastewater during a coagulation process: Significance of organic polymers, Journal of Environmental Sciences 26, 231, 2014.

6. MARANON E., VAZQUEZ I., RODRIGUEZ J., CASTRILLON L., FENANDEZ Y., LOPEZ H., Treatment of coke wastewater in a sequential batch reactor (SBR) at pilot plant scale, Bioresource Technology 99, 4192, 2008.

7. DÍEZ M.A., ALVAREZ R., BARRIOCANAL C., Coal for metallurgical coke production: predictions of coke quality and future requirements for cokemaking, Coal Geology 50, 389, 2002.

8. OZGA-BLASCHKE U., Coking coal management, IGSMiE Publisher, Cracow, 2010 [In Polish].

9. BLASCHKE W., GRUDZIŃSKI Z., LORENZ U., OZGA BLASCHKE U., OLKUSKI T., STALA-SZLUGAJ K., The origin, form and content of chlorine in black coal, Scientific Papers of IGSMiE of Polish Academy of Science, 77, 23, 2010 [In Polish].

10. OSMÓLSKI J., The role of the equalization tank in industrial wastewater treatment at „Przyjaźń” cokemaking plant, Coke Magazin, 10 (20), 4, 2013 [In Polish].

11. TATARA M., TATARA A., HUMMER W., KOMOSIŃSKI B., The method of the wet coke quenching: current state and development perspectives in reffer to BAT requirement change, conference materials „Koksownictwo 2010”, Zakopane, 2010 [in Polish].

12. GERASOMOV S.V., KOZYREVA S.V., NEKRASOV N.S., Laboratory monitoring of biochemical wastewater treatment. 2. Quantitative chemical analysis: A review, Coke and Chemistry, 57 (2), 75, 2014.

13. WASIELEWSKI R., SOBOLEWSKI A., Industrial utilization of spent ion-exchange resin in the coke battery, Coke and Chemistry, 54 (2), 66, 2011.

14. FIGA J., STELMACH S., Prediction of chlorine content in coke, Karbo, 3 (2), 159, 2006 [In Polish]

15. ZHANG Q., WU X., FENG A., SHI M., Prediction of coke quality at Baosteel, Fuel Proces. Technol., 86, 1, 2004.

16. MIELCZAREK K., BOHDZIEWICZ B., KWARCIAKKOZŁOWSKA A., Coking plant wastewater treatment in integrated system combining volume coagulation and advanced oxidation with pressure membrane techniques, Civil and Envi. Engin. Rep., 7, 83, 2011.

17. QI R., YANG K., YU Z., Treatment of cokeplant wastewater by SND fixed biofilm hybrid system, Journal of Envi. Sci., 19 (2), 153, 2006 